\title{
Evaluasi Mikroklimat dalam Kandang Menggunakan Tinggi Atap Kandang Berbeda yang Berkaitan dengan Respon Fisiologis Sapi Bali Dewasa di Kecamatan XIV Koto Kabupaten Mukomuko
}

\author{
Microclimate Evaluation in Housing Using Different Height Level Roof Related to \\ Physiological Responses of Mature Bali Cattle in District XIV Koto Mukomuko District
}

\author{
D. Suherman, S. Muryanto dan E. Sulistyowati
}

Jurusan Peternakan, Fakultas Pertanian, Universitas Bengkulu. Jl. W.R. Supratman Kandang Limun, Bengkulu 38371. Tel./Fax. +62-736-21290, Koresponden e-mail : dadangsuherman707@yahoo.com

\begin{abstract}
ABSTRACK
The study aimed to evaluate the respiratory rate, heart rate and rectal temperature of mature Bali cattle, which is related to the temperature and humidity of the air within the enclosure at different roof height of the enclosure. The housing was made up of two different housing roofs, namely 200-250 cm (housing I) and housing roof height> 250-300 cm (housing II). This study used 40 mature cows of Bali cattle, at each height of different housing roof as many as 20 heads. The research method was done by direct observation and description, and using the follow-up analysis (Multiple Linear Regression), observation was done three times per day, such as morning (07.00-09.00 WIB), noon (11.30-13.30 WIB) and afternoon (16.00-18.00 WIB ). The observed variables were microclimate housing (temperature and humidity) and physiological response of mature Bali cattle (respiratory rate, heart rate and rectal temperature) at different roof height of the housing. The results showed that the height of the roof of different housing had an effect on the temperature and humidity of the air in the cage, which was related to respiratory rate, heart rate and rectal temperature of mature Bali cattle.
\end{abstract}

Key words: Housing roofs, microclimate housing, physiological response, mature Bali cattle.

\begin{abstract}
ABSTRAK
Penelitian ini untuk mengevaluasi frekuensi pernapasan, denyut jantung dan suhu rektal sapi Bali dewasa, yang berkaitan dengan mikroklimat dalam kandang (suhu dan kelembaban udara) pada tinggi atap kandang yang berbeda. Kandang terdiri dari dua tinggi atap kandang yang berbeda, yaitu 200-250 cm (Kandang I) dan tinggi atap kandang >250-300 cm (Kandang II). Penelitian dilaksanakan selama satu bulan, dari tanggal 25 April 2017 sampai 28 Juni 2017 di kandang peternak di Kec. XIV Koto, Kab. Mukomuko. Penelitian ini menggunakan ternak Sapi Bali dewasa sebanyak 40 ekor, pada masing-masing tinggi atap kandang yang berbeda sebanyak 20 ekor. Metode penelitian dengan cara pengukuran langsung dan deskripsi, pengukuran dilakukan sebanyak tiga kali, yaitu pagi, siang, dan sore. Variabel yang diamati meliputi respon fisiologis Sapi Bali dewasa dan mikroklimat pada tinggi atap kandang yang berbeda, yang dideskripsikan dan dianalisis menggunakan persamaan regresi. Tinggi atap kandang memberikan pengaruh terhadap mikroklimat dalam kandang, semakin tinggi atap kandang mempengaruhi penurunan suhu udara dan peningkatan kelembaban udara dalam kandang. Frekuensi pernapasan dan denyut jantung meningkat seiring dengan meningkatnya suhu udara dan kelembaban udara dalam kandang.
\end{abstract}

Kata kunci: Tinggi atap kandang, mikroklimat kandang, respon fisiologis, sapi bali dewasa.

\section{PENDAHULUAN}

Sapi potong merupakan salah satu ternak penghasil daging di Indonesia. Namun demikian, produksi daging sapi dalam negeri belum mampu memenuhi kebutuhan karena populasi dan tingkat produktivitas ternak rendah (Direktorat Jenderal Peternakan, 2007; Syadzali, 2007). Kebutuhan protein hewani semakin 
meningkat sejalan dengan meningkatnya kesadaran masyarakat terhadap pentingnya gizi yang seimbang, pertambahan penduduk dan meningkatnya daya beli masyarakat (Direktorat Jenderal Peternakan, 2006). Rendahnya populasi sapi potong antara lain disebabkan sebagian besar ternak dipelihara oleh peternak berskala kecil dengan lahan dan modal terbatas (Kariyasa, 2005; Mersyah, 2005).

Faktor pendorong pengembangan sapi potong, antara lain permintaan pasar terhadap daging sapi semakin meningkat, ketersediaan tenaga kerja, adanya kebijakan pemerintah yang mendukung upaya pengembangan sapi potong, hijauan pakan dan limbah pertanian tersedia sepanjang tahun, dan usaha peternakan sapi lokal tidak terpengaruh oleh krisis ekonomi global (Kariyasa, 2005; Gordeyase et al., 2006; Nurfitri, 2008).

Umumnya ternak ruminansia yang dikembangkan di Kabupaten Mukomuko, Kecamatan XIV KOTO adalah Sapi Bali dan Kerbau. Sangat banyak masyarakat yang beternak Sapi Bali namun kurang memiliki kandang, karena pemeliharaannya banyak yang diliarkan. Kondisi kandang Sapi Bali yang digunakan beragam, diantaranya terlihat dari ketinggian atap kandang. Oleh karena itu harus dilakukan penelitian mengenai respon fisiologis Sapi Bali yang dipengaruhi oleh tinggi atap kandang yang berbeda.

Kandang merupakan tempat ternak dapat bernaung, karena fungsi kandang dapat memberikan naungan dari panas dan hujan. Selain itu, kandang sebagai tempat berlangsungnya proses produksi ternak. Untuk mendukung keberlangsungan produksi pada ternak, maka perlu menciptakan kondisi kandang yang nyaman. Kenyamanaan dalam kandang dipengaruhi kondisi mikroklimat yang akan mempengaruhi respon fisiologis ternak. Respon fisoilogis pada ternak akan berpengaruh terhadap produksi dan keberlangsungan hidupnya.

Suhu kandang merupakan mikroklimat kandang yang berpengaruh terhadap laju respirasi, apabila suhu kandang cukup tinggi maka akan berpengaruh terhadap laju respirasi pada sapi lebih tinggi. Salah satu upaya ternak untuk melepaskan beban panas dengan cara evaporasi melalui saluran pernapasan. Bernafas pendek - pendek dan cepat merupakan tanda bahwa hewan kepanasan (Putra, 2012). Reaksi sapi terhadap perubahan suhu yang dilihat dari respon pernapasan dan denyut jantung merupakan mekanisme dari tubuh sapi untuk mengurangi atau melepaskan panas yang diterima dari luar tubuh ternak.

Peningkatan denyut jantung merupakan respon dari tubuh ternak untuk menyebarkan panas yang diterima ke dalam organ-organ yang lebih dingin. Respon pernapasan merupakan respon tubuh ternak untuk membuang atau mengganti panas dengan udara di sekitarnya. Jika kedua respon tersebut tidak berhasil mengurangi tambahan panas dari luar tubuh ternak, maka suhu organ tubuh ternak akan meningkat, sehingga ternak mengalami cekaman panas (Anderson, 1983). Respon fisiologis sapi perah meningkat signifikan sejalan dengan meningkatnya suhu lingkungan. Suhu udara meningkat secara signifikan dari $38,7^{\circ} \mathrm{C}$ (suhu lingkungan $26,7^{\circ} \mathrm{C}$ ) menjadi $38,9^{\circ} \mathrm{C}$ (suhu lingkungan $27,1^{\circ} \mathrm{C}$ ) dan frekuensi pernapasan meningkat signifikan dari 54,9 kali/menit (suhu lingkungan $27,1^{\circ} \mathrm{C}$ ) menjadi $67,5 \mathrm{kali} / \mathrm{menit}$ (suhu lingkungan $29,9^{\circ} \mathrm{C}$ ) (Sulistyowati, 1991). 
Besarnya penambahan panas yang berasal dari radiasi matahari di daerah tropis dapat mencapai empat kali lebih besar dari pada produksi panas hasil metabolisme (Thwaites, 1985). Besarnya penambahan panas ini tergantung pada ukuran tubuh ternak. Semakin kecil ukuran tubuh seekor ternak, akan mendapatkan penambahan panas yang lebih tinggi dari pada ternak yang lebih besar ukuran tubuhnya.

Perolehan panas dari luar tubuh (heat gain) akan menambah beban panas bagi ternak, bila suhu udara lebih tinggi dari suhu nyaman. Sebaliknya, akan terjadi kehilangan panas tubuh (heat loss) apabila suhu udara lebih rendah dari suhu nyaman. Perolehan dan penambahan panas tubuh ternak dapat terjadi secara sensible melalui mekanisme radiasi, konduksi dan konveksi. Jalur utama pelepasan panas melalui mekanisme evaporative heat loss dengan jalan melakukan pertukaran panas melalui permukaan kulit (sweating) atau melalui pertukaran panas disepanjang saluran pernapasan (panting) (Purwanto, 1993) dan sebagian melalui feses dan urin (McDowell, 1972).

Selain memilih bahan atap yang berkonduktivitas rendah, usaha lain yang ditempuh untuk modifikasi lingkungan mikro di dalam kandang adalah dengan memperbesar ukuran kandang. Salah satunya adalah dengan meninggikan atap kandang, sehingga volume udara dan aliran udara yang masuk ke dalam kandang menjadi lebih besar dan pergantian udara lebih cepat sehingga suhu dalam kandang menurun (Carpenter, 1981).Daerah-daerah yang cerah dengan sinar matahari penuh, tinggi atap kandang sebaiknya antara 3,6 4,2 $\mathrm{m}$, sedangkan daerah agak berawan tinggi atap kandang antara 2,1 - 2,7 m. Ketinggian kandang tersebut cukup efektif membatasi difusi radiasi matahari yang diterima ternak di dalam kandang (Hahn, 1985). Ketinggian atap kandang untuk daerah tropis basah berkisar antara $2-3 \mathrm{~m}$ dan untuk daerah beriklim panas kering antara 4-5 m (McDowell, 1972), serta antara 3-4 m untuk daerah semi arid (Wiersma et al., 1984).

Perbedaan ketinggian atap kandang sangat mempengaruhi respons fisiologis sapi. Respon fisiologis yang berubah antara lain suhu kulit, suhu rektal, suhu tubuh, frekuensi pernapasan dan denyut jantung. Respon produksi yang berubah yaitu konsumsi makan dan minum, serta pertambahan bobot badan (Santoso, 1996). Ketinggian atap kandang yang terbuat dari bahan seng sebaiknya 3,5 m dari lantai kandang (Basyarah, 1995). Ketinggian atap kandang yang digunakan juga dapat mempengaruhi kondisi mikroklimat dalam kandang. Dalam pembuatan kandang yang dilakukan peternak tentu terdapat perbedaan dari ketinggian atap kandang yang digunakan. Perbedaan ini dipengaruhi oleh nilai ekonomis yang diinginkan oleh peternak. Ketinggian atap kandang akan berpengaruh terhadap sirkulasi udara dalam kandang dan jumlah produksi panas. Semakin tinggi kandang akan menghasilkan sirkulasi udara yang baik serta produksi panas yang dihasilkan dari atap kandang semakin sedikit. Kandang yang digunakan dalam penelitian merupakan kandang individual dan bahan atap kandang terbuat dari seng.

Pengukuran evaluasi lingkungan mikroklimat dibutuhkan untuk mengetahui pengaruh lingkungan terhadap produktifitas sapi dalam kandang. Evaluasi lingkungan mikroklimat yang dilakukan diantaranya suhu dan kelembaban udara kandang. Cuaca disekitar lingkungan kandang memiliki pengaruh terhadap 
respon fisiologis ternak. Pengukuran respon fisiologis dilakukan melalui pengukuran denyut jantung, frekuensi pernapasan dan suhu rektal (Suherman, 2013).

\section{MATERI DAN METODE}

Penelitian ini dilaksanakan selama dua bulan, dari tanggal 25 April 2017 sampai 28 Juni 2017 di kandang peternak di Kec.XIV Koto, Kab. Mukomuko. Penelitian dilaksanakan pada tiga Desa yang memiliki potensi ternak Sapi Bali yang cukup tinggi. Tiga Desa yang termasuk dalam penelitian tersebut adalah Desa Rawa Bangun (SP.10), Desa Tanjung Mulia (SP.09), dan Rawa mulya (SP.07).

Alat yang digunakan dalam penelitian ini adalah sepatu boot, termometer klinik, higrometer, stopwatch, meteran, kamera dan alat bantu tulis lainnya. Penelitian ini menggunakan Sapi Bali dewasa sebanyak 40 ekor, yang masing-masing pada setiap kandang dengan tinggi atap kandang berbeda berjumlah 20 ekor.

Survei kandang dilaksanakan pada 25 Februari 2017. Kandang memiliki atap yang terbuat dari seng, lantai terbuat dari semen, dan kandang bersifat individual. Kandang memiliki dua tinggi atap kandang yang berbeda, yaitu 200-250 cm (Kandang I) dan tinggi atap kandang $>250-300 \mathrm{~cm}$ (Kandang II). Izin penelitian dilakukan sebelum penelitian berlangsung, meliputi izin penelitian yang dikeluarkan oleh Fakultas Pertanian dan Pemerintah Daerah setempat. Evaluasi kandang dilakukan secara langsung dengan melakukan pengukuran terhadap kandang, untuk mengetahui rata-rata ukuran dan luas kandang pada masing-masing tinggi atap kandang yang berbeda.
Evaluasi lingkungan mikroklimat dalam kandang, meliputi suhu dan kelembaban udara, yang dilakukan dengan mengukur secara langsung pada setiap tinggi atap kandang berbeda terhadap respon fisiologis sapi Bali dewasa. Suhu udara dalam kandang diukur dengan menggunakan termometer bola kering (Lakitan, 1994). Suhu udara dalam kandang diukur menggunakan termometer bola kering yang digantungkan di dalam kandang, dengan satuan $\left({ }^{\circ} \mathrm{C}\right)$.

Kelembaban udara diukur menggunakan Hygrometer dengan menggantungkan higrometer di dalam kandang. Hygrometer dapat menganalisis kelembaban udara suatu tempat, baik di dalam maupun di luar ruangan. Hasil dari pengukuran menggunakan higrometer berupa angka kelembaban udara (\%) dan angka suhu kering $\left({ }^{\circ} \mathrm{C}\right)$ suatu tempat. Hygrometer adalah alat yang berfungsi untuk mengukur kelembaban udara yang merupakan pengembangan dari psikrometer. Psycrometer merupakan sebuah higrometer sederhana. Psikometer berfungsi sebagai pengukur kelembaban udara yang terdiri dari termometer bola kering dan basah. Alat ini diletakkan tegak, bola yang mengandung air raksa dari termometer bola basah dibungkus dengan kain yang dibasahi terus menerus dengan air destilasi melalui benang yang tercelup pada sebuah mangkok kecil (Tjasyono, 2004).

Frekuensi pernapasan diamati dengan cara memperhatikan kembang kempis rongga perut Sapi pada saat proses keluar masuknya udara melalui saluran pernapasan. Pengamatan frekuensi pernapasan dihitung dalam waktu satu menit (kali/menit), banyaknya pengamatan yang dilakukan tiga kali per ekor ternak dalam sehari, yaitu pagi (07.00-09.00 
WIB), siang (11.30-13.30WIB), dan sore (16.00-18.00).

Denyut jantung diamati melalui urat nadi (Vena Cava Superior) yang terdapat di leher Sapi dengan cara sedikit menekan menggunakan jari tangan, serta menghitung denyut selama satu menit dengan satuan (kali/menit). Pengukuran dilakukan sebanyak tiga kali setiap ekor ternak dalam sehari, yaitu pagi, siang, dan sore. Mengukur suhu rektal diukur dengan memasukkan termometer klinik sedalam $10 \mathrm{~cm}$ selama satu menit $\left({ }^{\circ} \mathrm{C}\right)$. Pengukuran dilakukan sebanyak tiga kali dalam sehari, yaitu pagi, siang, dan sore.

\section{Rancangan Penelitian}

Penelitian ini dilakukan dengan cara pengamatan dan pengukuran lingkungan mikroklimat dalam kandang (suhu dan kelembaban udara) dan respon fisiologi sapi Bali dewasa (frekuensi pernapasan, denyut jantung dan suhu rektal) pada kandang dengan tinggi atap kandang yang berbeda. Pengukuran dilakukan sebanyak tiga kali dalam sehari, pada pukul 07.00-09.00 WIB (pagi), 11.3013.30 WIB (siang) dan 16.00-18.00 WIB (sore). Untuk memperoleh data penelitian membutuhkan waktu kurang lebih selama dua bulan. Penelitian dilaksanakan pada saat matahari cerah. Sapi Bali yang diukur dan diamati dalam keadaan sehat, pemeliharaannya tidak dimandikan dan sudah berumur dewasa.

Sapi Bali dipelihara dalam kandang individu, sehingga untuk melakukan pengukuran respon fisiologis mudah dilakukannya. Selain itu juga, respon fisiologis yang akan diukur dapat memberikan data yang sesuai dengan tujuan penelitian yaitu mengetahui pengaruh mikroklimat dalam kandang terhadap respon fisiologis Sapi Bali dewasa pada kandang dengan tinggi atap kandang berbeda.

\section{Analisis Data}

Pengolahan data dilakukan secara deskripsi, dengan mendeskripsikan variabel hasil penelitian, meliputi evaluasi kandang, mikroklimat dalam kandang (suhu dan kelembaban udara), pengamatan dan pengukuran fisiologis (frekuensi pernapasan, denyut jantung, dan suhu rektal).Menggunakan analisis lanjutan Analisis Regresi Linear Berganda (persamaan regresi, korelasi linear berganda, determinasi dan Uji t). Tiga Variabel Dependen dalam respon fisiologis Sapi Bali dewasa yang akan dianalisis, yaitu frekuensi pernapasan $\left(\mathrm{Y}_{1}\right)$, denyut jantung $\left(\mathrm{Y}_{2}\right)$ dan suhu rektal $\left(\mathrm{Y}_{3}\right)$. Analisis ini memiki dua Variabel Independen dalam mikroklimat kandang, yaitu suhu udara $\left(\mathrm{X}_{1}\right)$ dan kelembaban udara $\left(\mathrm{X}_{2}\right)$. Data yang digunakan adalah data rata-rata dari setiap variabel yang diamati pada ketinggian atap kandang yang berbeda.

\section{HASIL DAN PEMBAHASAN}

\section{Evaluasi Kandang}

Evaluasi kandang dilakukan secara langsung dengan melakukan pengukuran untuk mengetahui rata-rata ukuran panjang, lebar dan luas kandang pada masingmasing tinggi atap kandang yang berbeda. Kandang I dengan tinggi atap 200-250 cm dan Kandang II dengan tinggi atap >250$300 \mathrm{~cm}$. Hasil penelitian menunjukkan bahwa bahan atap kandang terbuat dari seng, lantai kandang terbuat dari semen, dan dinding kandang tipe terbuka. Rataan panjang, lebar dan luas kandang pada tinggi atap yang berbeda terdapat pada Tabel 1.

Data rataan yang terdapat pada Tabel 1 menunjukkan bahwa ukuran 
kandang memiliki perbedaan pada setiap tinggi atap kandang. Kandang II memiliki ukuran panjang, lebar dan luas yang lebih besar dari pada ukuran Kandang I. Semakin luas kandang dan semakin tinggi atap akan memberikan pengaruh terhadap sirkulasi udara dalam kandang semakin besar, sehingga dapat menurunkan suhu dalam kandang. Rataan pada Tabel 1 menunjukkan luas kandang Sapi Bali dewasa pada Kandang I sebesar 4,2 $\mathrm{m}^{2}$ dan Kandang II sebesar 4,8 $\mathrm{m}^{2}$.

Hasil penelitian menunjukkan bahwa luas kandang individu Sapi Bali memenuhi persyaratan, baik Kandang I maupun Kandang II. Hal tersebut tidak jauh berbeda dengan pendapat Rasyidi \& Hartati (2007), bahwa kandang individu sapi potong memiliki panjang 2,5 meter, lebar 1,5 meter dan memiliki luas 3,7 meter.
Tabel 1. Rataan panjang, lebar, dan luas kandang pada tinggi atap kandang berbeda

\begin{tabular}{cccc}
\hline Kandang & $\begin{array}{c}\text { Panjang } \\
(\mathrm{cm})\end{array}$ & $\begin{array}{c}\text { Lebar } \\
(\mathrm{cm})\end{array}$ & $\begin{array}{c}\text { Luas } \\
(\mathrm{cm})\end{array}$ \\
\hline I & 285 & 146 & 4,2 \\
II & 309 & 157 & 4,8 \\
\hline
\end{tabular}

Keterangan: I: Tinggi kandang 200-250 cm; II: tinggi atap kandang $>250-300 \mathrm{~cm}$

\section{Mikroklimat dalam Kandang}

Evaluasi mikroklimat dalam kandang yang diukur yaitu suhu dan kelembaban udara dalam kandang. Evaluasi lingkungan mikroklimat kandang dilakukan dengan mengukur secara langsung pada pagi, siang dan sore hari, evaluasi lingkungan mikroklimat pada tinggi atap kandang yang berbeda memiliki pengaruh terhadap suhu dan kelembaban yang disajikan pada Tabel 2.

Tabel 2. Rataan suhu dan kelembaban udara dalam kandang pada tinggi atap kandang berbeda

\begin{tabular}{ccccc}
\hline \multirow{2}{*}{ Kandang } & \multicolumn{3}{c}{ Suhu udara $\left({ }^{\circ} \mathrm{C}\right)$} & \multirow{2}{*}{ Rata-rata harian } \\
\cline { 2 - 4 } & Pagi & Siang & Sore & $31 \pm 0$ \\
I & $27 \pm 0,6$ & $35 \pm 0,3$ & $31 \pm 0,8$ & $30 \pm 0,5$ \\
II & $26 \pm 0,1$ & $34 \pm 0,4$ & $31 \pm 1,2$ & \\
& & Kelembaban udara $(\%)$ & & $71 \pm 1,1$ \\
I & $78 \pm 2,6$ & $55 \pm 1,4$ & $70 \pm 2$ & $75 \pm 1,1$ \\
II & $92 \pm 0,3$ & $60 \pm 1,7$ & $74 \pm 2,3$ & \\
\hline
\end{tabular}

Keterangan: I: Tinggi atap kandang 200-250 cm; II: Tinggi atap kandang $>250-300 \mathrm{~cm}$.

Suhu udara dalam kandang merupakan salah satu unsur mikroklimat dalam kandang yang diukur pada setiap tinggi atap kandang yang berbeda. Hasil penelitian menunjukkan bahwa rataan suhu udara Kandang I lebih tinggi dari pada Kandang II, tinggi atap kandang yang berbeda memiliki selisih suhu kandang yang berbeda. Hasil penelitian bahwa suhu udara kandang minimum pada pengamatan pagi hari sebesar $26^{\circ} \mathrm{C}$, suhu maksimum sebesar $35,5^{\circ} \mathrm{C}$ pada saat pengukuran siang hari. Rataan suhu udara minimum pada pagi hari di Kandang I sebesar $27^{\circ} \mathrm{C}$ dan Kandang II sebesar $26^{\circ} \mathrm{C}$, suhu udara maksimum pada siang hari di Kandang I sebesar $35^{\circ} \mathrm{C}$ dan pada Kandang II sebesar $34^{\circ} \mathrm{C}$. Rata-rata suhu udara harian Kandang I sebesar $31^{\circ} \mathrm{C}$ dan pada Kandang II sebesar $30^{\circ} \mathrm{C}$. Terdapat perbedaan suhu udara kandang dipengaruhi luas dan tinggi kandang, sehingga suhu udara harian Kandang II lebih rendah dari pada Kandang I.

Hasil penelitian tersebut sesuai dengan hasil penelitian Suherman et al., 
(2013), bahwa nilai suhu $22,79-32^{\circ} \mathrm{C}$ menunjukkann kondisi lingkungan yang memberikan cekaman pada ternak sapi. Kisaran zona termonetral ternak berada pada suhu udara antara $5-25^{\circ} \mathrm{C}$ (Jones dan Stallings, 1999), suhu udara antara 13$25^{\circ} \mathrm{C}$ (McNeilly, 2001).

Ketinggian atap kandang yang lebih tinggi selain dapat meningkatkan sirkulasi udara, juga dapat mempengaruhi suhu udara dalam kandang. Hal tersebut sesuai dengan pendapat Nuriyas et al. (2010), bahwa radiasi matahari yang mengenai bahan atap kandang akan dirubah oleh lapisan bagian atas atap menjadi gelombang panjang (panas), diantarkan ke lapisan bagian dalam dengan cara konduksi dan dipancarkan ke ruangan kandang. Pancaran radiasi gelombang panjang ini merupakan bagian paling dominan mempengaruhi suhu udara dalam kandang, sehingga Kandang II memiliki sirkulasi udara lebih tinngi yang dapat menurunkan suhu udara dalam kandang.

Tingginya rata-rata suhu udara dalam kandang berpengaruh terhadap respon fisiologis Sapi Bali dewasa, meliputi frekuensi pernapasan, denyut jantung, dan suhu rektal. Suhu udara dalam kandang selama seharian memiliki titik minimum dan maksimum. Hal tersebut, menurut Ensminger (1971), terdapatnya puncak suhu udara maksimum dapat memberikan pengaruh stres panas terhadap Sapi Bali. Perubahan suhu udara dalam kandang dapat juga mempengaruhi perubahan denyut jantung dan frekuensi pernapasan.

Kelembaban udara dalam kandang merupakan unsur mikroklimat yang diukur secara lansung pada pagi, siang dan sore hari. Data rata-rata kelembaban udara pada tinggi atap kandang yang berbeda tercantum pada Tabel 2. Hasil penelitian yang tertera pada Tabel 2 menunjukkan bahwa terdapat perbedaan rata-rata kelembaban udara antara Kandang I dengan Kandang II, baik kelembaban udara pagi, siang, sore maupun rataan kelembaban udara harian. Kelembaban udara harian pada Kandang II sebesar $75 \%$ lebih tinggi dibandingkan dengan kelembaban udara di Kandang I sebesar $71 \%$. Hal tersebut menunjukkan bahwa semakin rendah suhu udara dalam kandang, maka semakin meningkat kelembaban udara dalam kandang. Hasil penelitian tersebut sejalan dengan hasil penelitian Yani et al. (2013), bahwa semakin rendah suhu udara dalam kandang sapi bali, maka kelembaban udara semakin meningkat. Rataan kelembaban udara minimum terjadi pada siang hari, baik di Kandang I sebesar55\% dan Kandang II sebesar 60\%. Kelembaban maksimum terjadi pada pagi hari di Kandang I sebesar $87 \%$ dan di Kandang II sebesar 92\%.Hasil pengukuran tersebut menunjukkan kelembaban udara sangat tinggi, kelembaban udara tersebut kurang sesuai karena diatas nornal. me kelembaban udara normal antara 50-60\% (McNielly, 2001). Kelembaban udara dalam kandang dipengaruhi suhu udara yang berada pada setiap tinggi atap kandang, selain itu ada faktor lain yang berpengaruh terhadap kelembaban udara kandang yang dikemukakan oleh Nuriyasa et al. (2010), bahwa kelembaban udara relatif yang terukur di dalam kandang tergantung pada sumber air yang ada dalam kandang, kecepatan angin yang berhembus dalam kandang dan suhu udara sebagai faktor pengendali evaporasi.

\section{Respon Fisiologis Sapi Bali}

Pengukuran respon fisiologis meliputi frekuensi pernapasan, denyut jantung, dan suhu rektal Sapi Bali dewasa pada tinggi atap kandang yang berbeda. 
Pengukuran respon fisiologis dilakukan sebanyak tiga kali, yaitu pagi, siang, dan sore hari. Hasil penetitian, rata-rata respon fisiologis Sapi Bali dewasa terdapat perbedaan pada setiap tinggi atap kandang, yang disajikan pada Tabel 3.

Tabel 3. Rataan frekuensi pernapasan, denyut jantung, dan suhu rektal sapi Bali dewasa pada tinggi atap kandang yang berbeda

\begin{tabular}{cllll}
\hline \multirow{2}{*}{ Kandang } & \multicolumn{3}{c}{ Frekuensi pernapasan (kali/menit) } & Rata-rata \\
\cline { 2 - 4 } & Pagi & Siang & Sore & $30 \pm 1$ \\
I & $27 \pm 1$ & $33 \pm 4$ & $29 \pm 1$ & $29 \pm 1$ \\
II & $27 \pm 1$ & $30 \pm 1$ & $29 \pm 1$ & $57 \pm 2$ \\
\hline \multicolumn{5}{c}{ Denyut jantung (kali/menit) } \\
\hline I & $51 \pm 2$ & $64 \pm 3$ & $57 \pm 4$ \\
II & $49 \pm 3$ & $56 \pm 4$ & $52 \pm 5$ & $52 \pm 3$ \\
\hline \multicolumn{5}{c}{ Suhu rektal $\left({ }^{\circ} \mathrm{C}\right)$} \\
I & $37,8 \pm 0,4$ & $38,5 \pm 0,2$ & $38,6 \pm 0,2$ & $38,3 \pm 0$ \\
\hline
\end{tabular}

Ket: I: Tinggi atap kandang 200-250 cm; II: Tinggi atap kandang >250-300 cm.

Frekuensi pernapasan merupakan respon fisiologis Sapi Bali dewasa yang diukur pada tinggi atap kandang yang berbeda. Hasil penelitian yang tertera pada Tabel 4 menunjukkan rata-rata frekuensi pernapasan harian berbeda, pada Kandang I sebesar $30 \mathrm{kali} / \mathrm{menit}$ dan Kandang II sebesar 29 kali/menit. Frekuensi pernapasan harian Sapi Bali dewasa yang terdapat pada Kandang I dan Kandang II masih nornal. Ensminger (1971), melaporkan bahwa frekuensi pernapasan sapi dewasa sehat pada daerah zona nyaman adalah 10-30 kali/menit. Hasil penelitian tersebut menunjukkan frekuensi pernapasan pada siang hari berbeda, antara Kandang I sebesar $33 \mathrm{kali} / \mathrm{menit}$ dan Kandang II sebesar 30 kali/menit. Suherman et al. (2013), melaporkan bahwa frekuensi pernapasan siang hari mengalami stres panas yang diakibatkan suhu dan kelembaban udara dalam kandang.

Penurunan suhu udara kandang menyebabkan peningkatan kelembaban udara kandang yang berpengaruh terhadap penurunan frekuensi pernapasan ternak Sapi Bali dewasa. Hasil tersebut sesuai dengan hasi penelitian Yani et al. (2013), bahwa semakin meningkat suhu udara lingkungan, maka semakin meningkat pula frekuensi pernapasan Sapi Bali. Berman (2005), bahwa cekaman panas sedang ditandai dengan terjadinya pelepasan panas tubuh melalui proses respirasi. Rataan frekuensi pernapasan minimum terjadi pagi hari dan maksimum pada siang hari. Hasil penelitian menunjukkan bahwa frekuensi pernapasan minimum sebesar $24 \mathrm{kali} /$ menit dan maksimum sebesar $42 \mathrm{kali} /$ menit.

Kandang I menunjukkan suhu udara harian sebesar $31{ }^{\circ} \mathrm{C}$ dan kelembaban udara $71 \%$, yang menunjukkan frekuensi pernapasan $30 \mathrm{kali} / \mathrm{menit}$. Kandang II sebesar suhu $30^{\circ} \mathrm{C}$ dan kelembaban $75 \%$, yang menunjukkan frekuensi pernapasan 29 kali/menit. Menurut Sulistyowati (1991), bahwa frekuensi pernapasan meningkat signifikan seiring dengan meningkatnya suhu lingkungan.

Denyut jantung merupakan respon fisiologis Sapi Bali dewasa yang diukur pada tinggi atap kandang yang berbeda. Data rata-rata denyut jantung Sapi Bali dewasa terdapat pada Tabel 3. Hasil pengukuran pada Tabel 3 menunjukkan rata-rata denyut jantung pada Kandang I 
dengan Kandang II berbeda, dikarenakan kelembaban udara dalam kandang mempengaruhi denyut jantung Sapi Bali dewasa. Hasil penelitian tesebut menunjukkan denyut jantung Sapi Bali dewasa pada pagi, siang dan sore di Kandang II lebih rendah dari pada denyut jantung di Kandang I, karena kelembaban udara Kandang II lebih tinggi berturutturut dari kelembaban udara Kandang I. Hasil tersebut sesuai dengan hasil penelitian Yani et al. (2013), bahwa suhu udara rendah dapat meningkatkan kelembaban udara yang mempengaruhi denyut jantung Sapi Bali, yang sangat sensitif terkena stres akibat peningkatan kelembaban.

Rataan denyut jantung yang tertera pada Tabel 3 menunjukkan perbedaan denyut jantung Sapi Bali pada pagi hari di Kandang I sebesar $51 \mathrm{kali} / \mathrm{menit}$ lebih tinggi dari pada di Kandang II sebesar 49 kali/menit. Siang hari di Kandang I menunjukkan denyut jantung Sapi Bali sebesar $64 \mathrm{kali} / \mathrm{menit}$ lebih tinggi dari pada Kandang II sebesar 56 kali/menit, karena suhu udara pada Kandang I meningkat dan kelembaban udara menurun. Menurut Chantalakhana dan Skunmun (2002), bahwa pada saat kelembaban udara tinggi dapat menjadi faktor penghambat evaporasi, sehingga evaporasi terjadi secara lambat dan kehilangan panas terbatas. Denyut jantung sore hari pada Kandang I sebesar 57 kali/menit lebih tinggi dari pada denyut jantung Kandang II sebesar $52 \mathrm{kali} / \mathrm{menit}$.

Denyut jantung rata-rata harian meningkat secara signifikan seiring dengan meningkatnya suhu udara dan menurunnya kelembaban, di Kandang I dengan suhu kandang $31^{\circ} \mathrm{C}$ dan kelembaban udara $71 \%$ dengan denyut jantung $57 \mathrm{kali} / \mathrm{menit}$ lebih tinggi dari denyut jantung di Kandang II sebesar $52 \mathrm{kali} /$ menit dengan suhu udara kandang $30^{\circ} \mathrm{C}$ dan kelembaban udara $75 \%$. Hasil penelitian ini sesuai dengan hasil penelitian Sulistyowati (1991), bahwa denyut jantung mengalami peningkatan secara signifikan seiring dengan meningkarnya suhu lingkungan. Rataan denyut jantung Sapi Bali dewasa dari kedua kandang menujukkan bahwa denyut jantung sapi di bawah nornal. Radostits et al. (2005), bahwa denyut jantung sapi pada kondisi normal berkisar antara $60-80$ kali/menit dan kondisi stres berat dapat mencapai 40 atau $120 \mathrm{kali} / \mathrm{menit}$.

Suhu rektal merupakan respon fisiologis Sapi Bali dewasa yang diukut pada tinggi atap kandang yang berbeda. Data rata-rata suhu rektal Sapi Bali dewasa terdapat pada Tabel 3. Hasil penelitian yang tertera pada Tabel 3 menunjukkan bahwa suhu rektal harian Sapi Bali dewasa yang berada pada tinggi atap kandang berbeda menunjukkan tidak adanya perbedaan. Suhu rektal Sapi Bali di Kandang I dan Kandang II dengan suhu rektal rata-rata harian sebesar $38,3{ }^{\circ} \mathrm{C}$. Suhu rektal minimum pada pagi hari di Kandang II sebesar $37,9^{\circ} \mathrm{C}$ lebih tinggi dari pada Kandang I sebesar $37,8^{\circ} \mathrm{C}$, disebabkan penurunan denyut jantung akibat tingginya kelembaban udara pada Kandang II mempengaruhi peningkatan suhu rektal. Hasil penelitian tersebut sesuai dengan pendapat Chantalakhana dan Skunmun (2002), bahwa pada saat kelembaban tinggi dapat menjadi faktor penghambat evaporasi, sehingga evaporasi terjadi secara lambat dan kehilangan panas terbatas.

Rataan suhu rektal pada sore hari di Kandang II sebesar $38,4^{\circ} \mathrm{C}$ lebih rendah dari pada Kandang I sebesar 38,6, dikarenakan terjadi peningkatan kembali kelembaban udara dalam Kandang II. 
Kondisi suhu rektal Sapi Bali masih normal, seperti yang dikemukakan oleh Ensminger (1971), bahwa sapi pada daerah zona nyaman memiliki suhu rektal 38,1$39^{\circ} \mathrm{C}$. Suhu rektal $38,3{ }^{\circ} \mathrm{C}$ pada suhu udara kandang 30 sampai $31{ }^{\circ} \mathrm{C}$ tidak mengalami kenaikan secara signifikan, dikarenakan suhu udara harian dalam kandang tidah berbeda, sehingga suhu rektal harian tidak terdapat perbedaan. Hasil penelitian tersebut tidak jauh berbeda dengan hasil penelitian Sulistyowati (1991), melaporkan bahwa rektal temperatur meningkat secara signifikan dari $38,7^{\circ} \mathrm{C}$ (suhu lingkungan $26,7^{\circ} \mathrm{C}$ ) menjadi $38,9^{\circ} \mathrm{C}$ (suhu lingkungan $27,1^{\circ} \mathrm{C}$ ). Menurut Kadarsih (2004), menerangkan bahwa dengan adanya suhu lingkungan yang tinggi atau rendah dari suhu tubuhnya maka ternak akan mempertahankan suhu tubuhnya yang konstan, oleh karena itu ternak akan memproduksi panas dalam tubuhnya dan mengeluarkannya kesekitar lingkungannya secara terus menerus.

\section{Regresi Berganda Respon Fisiologis terhadap Mikroklimat Kandang}

Respon fisiologis meliputi frekuensi pernapasan, denyut jantung dan suhu rektal Sapi Bali dewasa yang di pengaruhi mikroklimat dalam kandang (suhu dan kelembaba udara) pada tinggi atap kandang yang berbeda memiliki persamaan regresi berganda yang tertera pada Tabel 4 .

Tabel 4. Persamaan regresi berganda respon fisiologis Sapi Bali dewasa

\begin{tabular}{lcl}
\hline Respon fisiologis & Kandang & Persamaan regresi berganda \\
\hline Frekuensi pernapasan (kali/menit) & I & $\mathrm{Y}_{1}=85,897-1,475 \mathrm{X}_{1}-0,153 \mathrm{X}_{2}$ \\
& II & $\mathrm{Y}_{1}=-58,643+1,313 \mathrm{X}_{1}+0,632 \mathrm{X}_{2}{ }^{*}$ \\
\hline Denyut jantung (kali/menit) & I & $\mathrm{Y}_{2}=-119,026+1,602 \mathrm{X}_{1}+1,800 \mathrm{X}_{2}$ \\
& II & $\mathrm{Y}_{2}=156,050-2,943 \mathrm{X}_{1}-0,188 \mathrm{X}_{2}{ }^{*}$ \\
\hline Suhu rektal $\left({ }^{\circ} \mathrm{C}\right)$ & I & $\mathrm{Y}_{3}=36,862-0,096 \mathrm{X}_{1}+0,062 \mathrm{X}_{2}$. \\
& II & $\mathrm{Y}_{3}=61,999-0,387 \mathrm{X}_{1}-0,159 \mathrm{X}_{2}{ }^{*}$ \\
\hline
\end{tabular}

Ket: I = Tinggi atap kandang 200-250 cm; II = Tinggi atap kandang >250-300 cm; $Y_{1}=$ Frekuensi pernapasan; $\mathrm{Y}_{2}=$ Denyut jantung; $\mathrm{Y}_{3}=$ Suhu rektal; $\mathrm{X}_{1}=$ Suhu kandang; $\mathrm{X}_{2}=$ Kelembaban.

Persamaan regresi respon fisologis Sapi Bali dewasa yang tertera pada Tabel 4 menunjukkan pengaruh suhu dan kelembaban udara pada tinggi atap kandang yang berbeda dapat memberikan pengaruh yang berbeda terhadap respon fisiologis Sapi Bali. Persamaan regresi frekuensi pernapasan menunjukkan variabel suhu dan kelembaban udara berbanding terbalik antara Kandang I dan Kandang II, kerena variabel suhu dan kelembaban udara di Kandang I memiliki hubungan negatif terhadap frekuensi pernapasan, sedangkan variabel suhu dan kelembaban udara pada Kandang II memiliki hubungan positif terhadap frekuensi pernapasan. Kedua persamaan regresi frekuensi pernapasan berbanding terbalik, karena adanya penurunan suhu dan peningkatan kelembaban udara dalam Kandang II. Hasil penelitian tersebut sesuai denga hasil penelitian Yani et al. (2013), semakin meningkatnya suhu dan kelembaban udara, maka frekuensi pernapasan mengalami peningkatan.

Persamaan regresi denyut jantung menunjukkan variabel suhu dan kelembaban udara berbanding terbalik antara Kandang I dan Kandang II, kerena variabel suhu dan kelembaban udara di 
Kandang I memiliki hubungan positif terhadap denyut jantung, sedangkan variabel suhu dan kelembaban udara pada Kandang II memiliki hubungan negatif terhadap denyut jantung. Hasil penelitian Yani et al. (2013), menunjukkan bahwa pada suhu udara yang lebih rendah, denyut jantung Sapi Bali lebih sensitif terkena stres akibat peningkatan kelembaban udara dibanding dengan frekuensi pernapasan.

Persamaan regresi suhu rektal menunjukkan variabel suhu dan kelembaban udara berbanding berimpit antara Kandang I dan Kandang II, kerena variabel independen di Kandang I suhu udara memiliki hubungan negatif dan kelembaban udara memiliki hubungan positif terhadap suhu rektal, sedangkan variabel suhu dan kelembaban udara pada Kandang II memiliki hubungan negatif terhadap suhu rektal. Hasil penelitian dari analisis regresi memiliki output model summary yang tertera pada Tabel 5.

Tabel 5. Model summary analisis regresi

\begin{tabular}{lccccr}
\hline \multicolumn{1}{c}{ Dependent Variable } & Model & $\mathrm{R}$ & $\mathrm{R}^{2}$ & Adjusted $\mathrm{R}^{2}$ & \multicolumn{1}{c}{ Std. Error } \\
\hline Frekuensi pernapasan & I & 0,307 & 0,094 & $-0,012$ & $1,478 \pm 1$ \\
& II & 0,233 & 0,055 & $-0,057$ & $0,876 \pm 1$ \\
\hline Denyut jantung & I & 0,732 & 0,535 & 0,481 & $1,802 \pm 2$ \\
& II & 0,397 & 0,157 & 0,058 & $3,121 \pm 3,14$ \\
\hline Suhu rektal & I & 0,475 & 0,225 & 0,134 & $0,2394 \pm 0$ \\
& II & 0,394 & 0,155 & 0,056 & $0,1420 \pm 0,15$ \\
\hline
\end{tabular}

Ket: $\mathrm{I}=$ Tinggi atap kandang $200-250 \mathrm{~cm} ; \mathrm{II}=$ Tinggi atap kandang $>250-300 \mathrm{~cm}$.

Berdasarkan Tabel 5 diperoleh $\mathrm{R}$ frekuensi pernapasan di Kandang I sebesar 0,307, dan di Kandang II sebesar 0,233. Hal ini menunjukkan bahwa dari kedua kandang terjadi hubungan yang rendah antara suhu dan kelembaban udara kandang terhadap frekuensi pernapasan Sapi Bali. Korelasi atau $\mathrm{R}$ denyut jantung di Kandang I sebesar 0,732, dan di Kandang II sebesar 0,397.

Hal ini menunjukkan bahwa pada Kandang I terjadi hubungan yang kuat antara suhu dan kelembaban udara kandang terhadap denyut jantung Sapi Bali, sedangkan di Kandang II terjadi hubungan yang rendah antara suhu dan kelembaban udara dalam kandang terhadap denyut jantung Sapi Bali. Nilai $\mathrm{R}$ suhu rektal di Kandang I sebesar 0,475, dan di Kandang II sebesar 0,394. Hal ini menunjukkan bahwa dari kedua kandang terjadi hubungan yang rendah antara suhu dan kelembaban udara kandang terhadap suhu rektal Sapi Bali. Hasil analisis korelasi menunjukkan bahwa hasil penelitian pada Kandang I terjadi hubungan yang kuat antara suhu dan kelembaban udara terhadap denyut jantung.

Nilai t hitung suhu udara dalam Kandang I $(0,778<2,109)$ dan di Kandang II $(0,947<2,109)$, maka secara parsial suhu udara dalam kandang tidak berpengaruh signifikan terhadap frekuensi pernapasan Sapi Bali $(\mathrm{P}>0,05)$. Nilai $\mathrm{t}$ hitung kelembaban udara dalam Kandang I $(0,254<2,109)$ dan di Kandang II $(0,990<$ 2,109), maka secara parsial kelembaban udara dalam kandang tidak berpengaruh signifikan terhadap frekuensi pernapasan Sapi Bali ( $\mathrm{P}>0,05)$.

Nilai t hitung kelembaban udara dalam Kandang I (2,457 > 2,109), maka secara parsial kelembaban udara dalam Kandang I berpengaruh signifikan terhadap 
denyut jantung Sapi Bali $(\mathrm{P}<0,05)$. Nilai $\mathrm{t}$ hitung kelembaban udara di Kandang II $(0,083<2,109)$, maka secara parsial kelembaban udara dalam kandang tidak berpengaruh signifikan terhadap denyut jantung Sapi Bali ( $\mathrm{P}>0,05)$.

Berdasarkan nilai t hitung suhu udara dalam Kandang I $(-0,321<-2,109)$ dan di Kandang II $(-1,723<-2,109)$, maka secara parsial suhu udara dalam kandang tidak berpengaruh signifikan terhadap suhu rektal Sapi Bali $(\mathrm{P}>0,05)$. Nilai t hitung kelembaban udara dalam Kandang I (0,637 < 2,109), dan di Kandang II (-1,535 < 2,109), maka secara parsial kelembaban udara dalam kandang tidak berpengaruh signifikan terhadap suhu rektal Sapi Bali $(\mathrm{P}>0,05)$.

\section{KESIMPULAN}

Hasil penelitian dapat disimpulkan bahwa tinggi atap kandang memberikan pengaruh terhadap mikroklimat kandang, semakin tinggi atap kandang mempengaruhi penurunan suhu udara dan peningkatan kelembaban udara dalam kandang. Perbedaan mikroklimat dalam kandang akan memberikan pengaruh terhadap respon fisiologis Sapi Bali dewasa. Kelembaban udara kandang meningkat seiring dengan menurunnya suhu udara kandang. Frekuensi pernapasan dan denyut jantung meningkat seiring dengan meningkatnya suhu udara.

\section{DAFTAR PUSTAKA}

Anderson, B. E. 1983. Temperature Regulation and Environmental Physiology. In: Dukes'Physiology of Domestic Animal. 10 th ed. M. J. Swenson (Ed). Cornell Univ. Press. P. 719-726.
Basyarah, W. 1995. Pengaruh Ketinggian Naungan dari Bahan Seng terhadap Respons Termoregulasi Sapi Fries Holland Dara. Skripsi. Fakultas Peternakan, IPB, Bogor.

Berman, A. 2005. Estimates of heat stress relief needs for Holstein dairy cows. J Anim Sci. 83:1377-1384.

Carpenter, G. A. 1981. Ventilation System. In: Environmental Aspect of Housing for Animal Production. J.A. Clark (Ed). Butterwoths, London. p.331350 .

Chantalakhana, C. H., dan P. Skunmun. 2002. Sustainable Smallholder Animal Systems in the Tropics. Bangkok: Kasetsart University Perss.

Direktorat Jenderal Peternakan. 2006. Statistik Peternakan. Direktorat Jenderal Peternakan, Jakarta.

Direktorat Jenderal Peternakan. 2007. Statistik Peternakan. Direktorat Jenderal Peternakan, Jakarta.

Ensminger, M. E. 1971. Dairy Cattle Science. The Interstate Printers and Publisher. Inc. Danville, Illinois.

Gordeyase, I. K. M., R. Hartanto, dan W. D. Pratiwi. 2006. Proyeksi Daya Dukung Pakan Limbah Tanaman Pangan untuk Ternak Ruminansia di Jawa Tengah. J. Indon. Trop. Anim. Agric. 32(4): 285-292.

Hahn, G. L. 1985. Management and Housing of Farm Animal in Hot Environment. In : Stress Physiology of Livestock. Vol. 1. M.K. Yousef (Ed). CRC Press, Inc. Boca Raton, Florida. P. 159-168. 
Jones, G. M., Stallings, C. C., 1999. Reducing heat stress for dairy cattle. Virgina Cooperative Extension. Publication Number 404-420. http;//www.edu/index.html. [21 Juni 2017].

Kariyasa, K. 2005. Sistem integrasi tanaman ternak dalam perspektif reorientasi kebijakan subsidi pupuk dan peningkatan pendapatan petani. Jurnal Analisis Kebijakan Pertanian 3(1): $68-80$.

Lakitan, B. 1994. Dasar-dasar Klimatologi. PT. Raja Grafindo Persada. Jakarta

McDowell, R.E. 1972. Improvement of Livestock Production in Warm Climate. W.H. Freeman and Co., San Frascisco.p.1-128.

McNeilly AS. 2001. Reproduction, fertility, and development. CSIRO Publishing 13: $583-590$.

Mersyah, R. 2005. Desain sistem budi daya sapi potong berkelanjutan untuk mendukung pelaksanaan otonomi daerah di Kabupaten Bengkulu Selatan. Disertasi, Sekolah Pascasarjana, Institut Pertanian Bogor.

Nurfitri, E. 2008. Sistem Pemeliharaan dan Prokduvitas Sapi Potong pada Berbagai Kelas Kelompok Peternak di Kabupaten Ciamis. Skripsi. Fakultas Peternakan, Institut Petanian Bogor.

Nuriyasa, I. M. Puspani E., Sumatra I. G. N. 2010. Peningkatan Efisiensi Produksi Ayam Petelur Melalui Peningkatan Kenyamanan Kandang di Desa Bolangan, Journal Pengabdian Kepada Masyarakat, ISSN: 1412-0925.
Purwanto, B. P. 1993. Heat and Energy Balance in Dairy Cattle Under High Environmental Temperatute. Doctoral Thesis, Hiroshima University.

Putra, D. K. H. 2012. Fisiologi Hewan: Thermoregulasi. Udayana University Press. Denpasar.

Radostits, O. M., C. C. Gay and J. H. Arundel. 2005. Veterinary Medicine: A Textbook of the Diseases of Cattle, Sheep, Pigs And Horse. Blackwell Publishing Professional. Iowa, USA.

Rasyidi, A. dan Hartati. 2007. Petunjuk Teknis Perkandangan Sapi Potong. Lokasi Penelitian Sapi Potong. Gerati.

Santoso, A. B. 1996. Pengaruh Lingkungan Mikro terhadap Respons Fisiologi Sapi Dara Peranakan Fries Holland. Thesis. Program Pascasarjana, IPB, Bogor.

Suherman, D. 2013. Upper critical temperature of Fries Holland heifers based on physiological responseses for feeding management using Artificial Neural Network simulation. Disertasi. IPB, Bogor.

Suherman, D., B. P. Purwanto, W. Manalu dan I.G. Permana. 2013. Simulasi Artifical Neural Network untuk Menentukan Suhu Kritis pada Sapi Fries Holland Berdasarkan Respon Fisiologis. Jurnal Ilmu Ternak dan Veteriner. 18(1): 70-80.

Sulistyowati, E. 1991. Effects of Added Dietary $\mathrm{NaC} 1, \mathrm{KC} 1$, and $\mathrm{KHCO}_{3}$ on Production and Physiological Performances of Lactating Dairy During Heat Stress. Thesis. University of Kentucky. 
Syadzali, M.J. 2007. Efektivitas Penyuluhan Ternak Sapi Potong di Kabupaten Jeneponto Sulawesi Selatan (Studi kasus Kecamatan Kelara). Skripsi. Fakultas Peternakan, Institut Pertanian Bogor.

Thwaites, C.J. 1985. Physiological Responses and Productivity in Sheep. In : M.K. Yousef (Ed.). Stress Physiology in Livestock Vol. II: Ungulates. CRC Press Inc. Boca Raton, Florida.

Tyasyono, B. 2004. Klimatologi. Penerbit ITB. Bandung.

Weeth H.J, JE Hunter, EL Piper. 2008. Effect of salt water dehydration on temperature, pulse, and respiration of growing cattle. http://jas.fass.org [10 Juni 2017].

Wiersma, F., D.V. Armstrong, W.T. Welchert dan D.G. Lough. 1984. Housing system for dairy production under warm weather condition. World Animal Review, 50:16-23.

Yani, A., W. Al-Zahra dan B. P. Purwanto. 2013. Response of Heart and Respiratory Frequency Bali Cattle Based on Changes in Temperature and Humidity in the Wet Tropical Climates Using Artifical Neural Networks. Jurnal Ilmu Produksi dan Tehnologi Hasil Peternakan. 1(1): 54-62. 